\title{
Correction: A novel mutation of the calcium sensing receptor gene is associated with chronic pancreatitis in a family with heterozygous SPINKI mutations
}

\author{
Peter Felderbauer*, Peter Hoffmann, Henrik Einwächter, Kerem Bulut, \\ Nikolaus Ansorge, Frank Schmitz and Wolfgang E Schmidt
}

Address: Laboratory for Experimental Gastroenterology, Department of Internal Medicine I, St. Josef -Hospital, Ruhr-University of Bochum, Germany

Email: Peter Felderbauer* - peter.felderbauer@rub.de; Peter Hoffmann - ced-ambulanz@elis-stiftung.de;

Henrik Einwächter - henrik.einwaechter@rub.de; Kerem Bulut - kbulut@web.de; Nikolaus Ansorge - n.ansorge@gmx.de; Frank Schmitz - frank.schmitz@rub.de; Wolfgang E Schmidt - wolfgang.e.schmidt@rub.de

* Corresponding author

Published: 18 March 2004

BMC Gastroenterology 2004, 4:6
Received: 17 March 2004

Accepted: 18 March 2004

This article is available from: http://www.biomedcentral.com//47I-230X/4/6

(C) 2004 Felderbauer et al; licensee BioMed Central Ltd. This is an Open Access article: verbatim copying and redistribution of this article are permitted in all media for any purpose, provided this notice is preserved along with the article's original URL.

This table (Table 1) was omitted from the original article

[1].

Table I: Sequences of oligonucleotide primers used for the PCR of the CASR gene.

\begin{tabular}{|c|c|}
\hline CASR gene & Primer used for PCR and Sequencing \\
\hline \multirow[t]{2}{*}{ Exon 2} & 5'-ACTGCAGGGAGTGAACTGCT-3' \\
\hline & 5'-TTATTTTGCGTTTGGTGCAG-3' \\
\hline \multirow{2}{*}{ Exon 3} & 5'-CGATGATTCAAACCCAGCTT-3' \\
\hline & 5'-CCTGCTTCTTCTGATCCTGC-3' \\
\hline \multirow{2}{*}{ Exon 4 Part I } & 5'-AGAAAGCCACCTCCACAACA-3' \\
\hline & 5'-CAGATCTTGAGCCCCTCATC-3' \\
\hline \multirow[t]{2}{*}{ Exon 4 Part II } & 5'-TGGCCAGCCAGATCTTGC-3' \\
\hline & 5'-GCAGCCCAACTCTGCTTTAT-3' \\
\hline \multirow[t]{2}{*}{ Exon 5} & 5'-TGGGGCTTGTACTCATTCTT-3' \\
\hline & 5'-CTGGTTTTCTGATGGACAGC-3' \\
\hline \multirow[t]{2}{*}{ Exon 6} & 5'-CССТGACCCTACAACT-3' \\
\hline & 5'-AGAGGGGTTCCCTTAC-3' \\
\hline \multirow[t]{2}{*}{ Exon 7 Part I } & 5'-ACACATTTTAGTCTGGTGCC-3' \\
\hline & 5'-CATGCTGAAGGTGATGAAC-3' \\
\hline \multirow[t]{2}{*}{ Exon 7 Part II } & 5'-GCCGGAGAACTTCAATG-3' \\
\hline & 5'-CTCCCTAGCCCAGTCTT-3' \\
\hline
\end{tabular}

The patient was screened for published mutations in exons 2-6 (exon I is untranslated) of the CASR gene. PCR products were gel-purified and sequenced on an ABI PRISM 377 DNA sequencer (Applied Biosystems, Foster, CA) using the listed primers for PCR and sequencing.

\section{References}

I. Felderbauer Peter, Hoffmann Peter, Einwaechter Henrik, Bulut Kerem, Ansorge Nikolaus, Schmitz Frank, Schmidt Wolfgang E: A novel mutation of the calcium sensing receptor gene is associated with chronic pancreatitis in a family with heterozygous SPINKI mutations. BMC Gastroenterology 2003, 3:34. 


\section{Pre-publication history}

The pre-publication history for this paper can be accessed here:

http://www.biomedcentral.com/1471-230X/4/6/prepub

Publish with Bio Med Central and every scientist can read your work free of charge

"BioMed Central will be the most significant development for disseminating the results of biomedical research in our lifetime. " Sir Paul Nurse, Cancer Research UK

Your research papers will be:

- available free of charge to the entire biomedical community

- peer reviewed and published immediately upon acceptance

- cited in PubMed and archived on PubMed Central

- yours - you keep the copyright 